\title{
Next-Generation Sequencing Confirmation of Real-Time RT-PCR False Positive Influenza-A Virus Detection in Waterfowl and Swine Swab Samples \\ Lu H ${ }^{1 *}$, Yi Tang ${ }^{1}$, Lin Lin ${ }^{1}$ and David R Wolfgang²
}

${ }^{1}$ Wiley Lab / Avian Virology, Animal Diagnostic Laboratory, Department of Veterinary and Biomedical Sciences, The Pennsylvania State University, University Park, PA 16802, USA

${ }^{2}$ Bureau of Animal Health and Diagnostic Services, The Pennsylvania Department of Agriculture, 2305 North Cameron Street, Harrisburg, PA 17110 , USA.

\begin{abstract}
Surveillance for the Influenza A virus is the most important method used to monitor poultry and other animal species for the presence of the Influenza A viruses. Waterfowl and swine swab samples that tested positive for the Influenza A virus by real-time RT-PCR (rRT-PCR) but tested negative for the virus by virus isolation were further investigated in our recent studies using next-generation sequencing (NGS). A total of seven such pooled swab samples (four swine oral-pharyngeal (OPH) swab pools and three wild duck OPH and cloacal swab pools) were tested for influenza A virus by whole genome sequencing using NGS with the Illumina MiSeq system. Our sequencing results confirmed that none of these rRT-PCR positive samples (Ct-values of 22 to 28 ) contained Influenza $A$ virus contigs; instead, all the samples contained multiple non-target contig sequences mismatched to the rRT-PCR primer and probe sequences, which led to the positive rRT-PCR results. These genome sequence findings provide scientific evidence that the rRT-PCR false positive results were caused by non-target contigs and not by target viral RNA. Additionally, these samples tested negative for the influenza A virus by conventional RT-PCR (CRT-PCR), which suggests CRT-PCR can serve as an alternative approach for identifying rRT-PCR false positive results.
\end{abstract}

Keywords: Influenza A virus; Surveillance; Real-time RT-PCR false positive; Genome sequencing; Virus isolation

\section{Introduction}

Influenza A virus is a genus of the Orthomyxoviridae family of viruses and causes influenza in birds and some mammals [1-3]. Many wild birds and waterfowl are thought to be natural hosts of Influenza A viruses, also known as avian influenza viruses (AIVs), without necessarily exhibiting signs of infection [4-6]. The type of Influenza A virus that infects swine is named swine influenza virus (SIV) $[7,8]$. Influenza A viruses are negative-sense, single-stranded, segmented RNA viruses. The Influenza A subtypes are classified according to the type of hemagglutinin and neuraminidase surface proteins on the virus, designated $\mathrm{H}$ and $\mathrm{N}$, respectively. So far, 18 distinct $\mathrm{H}$ antigens ( $\mathrm{H} 1$ to $\mathrm{H} 18$ ) and 11 distinct $\mathrm{N}$ antigens (N1 to N11) have been identified [9]. H17 was isolated from fruit bats in 2012, and H18N11 was discovered in a Peruvian bat in 2013 [10,11].

The surveillance and rapid diagnosis of Influenza A viruses are essential strategies in the prevention and control of outbreaks $[12,13]$. Although the classic laboratory methods for virus isolation (VI) are used worldwide as standard assays, emerging novel technologies have been rapidly developed and applied to support influenza surveillance and diagnosis since outbreaks of $\mathrm{H} 5 \mathrm{~N} 1$ highly pathogenic avian influenza (HPAI) occurred in southeast Asia in early 2000 [14-18]. The newly developed virus detection assays consist primarily of monoclonal antibody-based antigen capture assays and various molecular assays, including conventional reverse transcription polymerase chain reaction (cRT-PCR), multiplex RT-PCR (mRT-PCR), real-time RT-PCR (rRT-PCR), real-time reverse transcription loop-mediated isothermal amplification (rRT-LAMP), duplex rRT-PCR (drRT-PCR), and rapid PCR-based molecular pathotyping of the AIV H5 and H7 subtypes. These newly developed techniques provide urgently needed alternatives for rapid diagnosis during AIV outbreaks [19-31].

The advanced molecular assay of real-time PCR (rPCR), also known as rRT-PCR, has completely revolutionized the detection of
DNA and RNA in the life sciences and molecular biology over the last decade [27,32]. The rPCR technology allows the detection of PCR amplification and the measurement of the reaction kinetics during the early phases of the reaction, thus providing a distinct advantage over cPCR detection [33-35]. Because rPCR detects the accumulation of amplicons as the reaction progresses, the data are acquired during the exponential phase of the PCR reaction. By contrast, $\mathrm{CPCR}$ methods use agarose gels or other post-PCR methods to detect PCR amplification at the final phase or the end-point of the PCR reaction; these methods are time consuming and may not be as precise as rPCR. The exponential phase, or real-time, is commonly considered to be the optimal point for data analysis, and rPCR is considered to be the easiest method for quantifying detected DNA and RNA. Theoretically, there is a quantitative relationship between the amount of DNA in the starting target sample and the amount of PCR product at any given cycle number $[34,35]$.

Despite these advantages, rPCR has some shortcomings, including easy cross-contamination, the need for expensive equipment and a high cost per test. Molecular assays can detect viral RNA or DNA from both live and dead viruses therefore, samples that are positive for virus detection by molecular assays but negative by VI are commonly interpreted as being positive for viral RNA but not for live viruses

*Corresponding author: Huaguang Lu, Wiley Lab / Avian Virology, Animal Diagnostic Laboratory, Department of Veterinary and Biomedica Sciences, The Pennsylvania State University, University Park, PA 16802, USA, Tel: +8148634369; Fax: 8148654717; E-mail: hxl15@psu.edu

Received September 07, 2016; Accepted September 26, 2016; Published September 28, 2016

Citation: Lu H, Tang Y, Lin L, Wolfgang DR (2016) Next-Generation Sequencing Confirmation of Real-Time RT-PCR False Positive Influenza-A Virus Detection in Waterfowl and Swine Swab Samples. Next Generat Sequenc \& Applic 3: 134 doi:10.4172/2469-9853.1000134

Copyright: ( $) 2016$ Lu H, et al. This is an open-access article distributed under the terms of the Creative Commons Attribution License, which permits unrestricted use, distribution, and reproduction in any medium, provided the original author and source are credited. 
[27,36-40]. However, we have recently conducted genome sequencing studies of samples that tested positive by rRT-PCR but not by VI and confirmed that the positive rRT-PCR results acquired in our research studies were actually false positives. In this report, we describe our diagnostic investigation using next-generation sequencing (NGS) and provide genome sequence evidence that identifies rRT-PCR false positives for Influenza A virus detection in wild duck and swine swab samples.

\section{Materials and Methods}

\section{Ethics statement}

All animal procedures were performed in accordance with the regulations of the Pennsylvania state university (PSU) animal welfare and ethics guidelines (http://www.research.psu.edu/training/ sari/teaching-support/animal-welfare-1) and approved by PSU Institutional animal care and use committees (IACUC). The swab sample collection, virus propagation and isolation test were carried out in our avian virology lab. All experimental protocols were approved by PSU institutional biosafety committee.

\section{Duck and swine swabs}

For Influenza A virus surveillance during our previous research studies, duck OPH and cloacal swabs were obtained from wild ducks in the northwest region of Pennsylvania, and swine OPH swabs were obtained from farm-raised pigs in the source of Pennsylvania. A total number of 50 wild duck swab pools obtained in three collections and 56 pig OPH swabs obtained in one collection were used in this study.

\section{rRT-PCR and VI}

All swab samples were processed for the detection of the Influenza $A$ virus by one-step rRT-PCR assay using influenza A virus matrix gene primers and probe per USDA-NVSL AI rRT-PCR protocol (NVSL-SOP-DVL-AV, SOP-AV-0001, NVSL, Ames, IA, USA, 2013). QIAGEN RNeasy (Spin columns) Mini Kit (250) (Cat No./ID: 74106) was used for viral RNA extraction. QIAGEN OneStep RT-PCR Kit (100) (Cat No./ID: 210212) was used for the RT-PCR reaction. ABI 7500 fast real-time PCR machine was used for the assay performance. One AIV reference strain H5N2 (A/H5N2/chicken/PA/7659/1985) and one AIV H11N9 (A/H11N9/duck/PA/02099/2012) positive duck $\mathrm{OPH}$ swab pool of surveillance case stored in our lab were used for RNA extraction positive controls. The extracted H5N2 and H11N9 RNAs and also AIV matrix RNA obtained from USDA-NVSL were used for rRT-PCR positive controls. Wild duck OPH-CS swabs and farm-raised pig OPH swabs previously tested negative were used for RNA extraction and rRT-PCR negative controls. Swab samples that tested positive for the Influenza A virus by the rRT-PCR were repeated one or two times to confirm the positive rRT-PCR results, and then were subjected to VI using 9 to 11 day old specific-pathogen-free (SPF) embryonating chicken eggs (ECE) [41].

\section{cRT-PCR}

First, the rRT-PCR products $(10 \mu \mathrm{l}$ of PCR product mixed with $2 \mu \mathrm{l}$ of loading dye/sample) were loaded onto an agarose gel (1.0\% to $1.2 \%)$ and electrophoresed to test for the presence of a true PCR band in each sample. Second, if the rRT-PCR products contained PCR bands, the same RNAs that tested positive by rRT-PCR were used for CRT-PCR with the Influenza A group primers designed in our previous studies [25].

\section{NGS}

Wild duck and swine swab samples that resulted in strong positive signals by rRT-PCR (Ct-values <30) but that tested negative by VI and CRT-PCR, were used for whole genome sequencing by NGS with

\begin{tabular}{|c|c|c|c|c|}
\hline Serial No. & Animal ID and Type of swabs & rRT-PCR Ct-Value & cRT-PCR gel band & Virus Isolation \\
\hline 1 & Duck/OPH-CS/31477-3 & 30.36 & - & - \\
\hline 2 & Duck/OPH-CS/31477-4* & 22.45 & - & - \\
\hline 3 & Duck/OPH-CS/31477-5* & 28.35 & - & - \\
\hline 4 & Duck/OPH-CS/31968-4 & 22.45 & - & - \\
\hline 5 & Duck/OPH-CS/31968-11 & 27.32 & - & - \\
\hline 6 & Duck/OPH-CS/31968-13 & 29.78 & - & - \\
\hline 7 & Duck/OPH-CS/32646-7* & 26.72 & - & - \\
\hline 8 & Duck/OPH-CS/32646-9 & 31.45 & - & - \\
\hline 9 & Duck/OPH-CS/32646-10 & 33.46 & - & - \\
\hline 10 & Swine /OPH/Y045-Y046 & 33.83 & - & - \\
\hline 11 & Swine /OPH/Y047-Y048* & 24.67 & - & - \\
\hline 12 & Swine /OPH/Y049-Y050 & 29.42 & - & - \\
\hline 13 & Swine /OPH/Y051-Y052* & 22.74 & - & - \\
\hline 14 & Swine /OPH/Y053-Y054* & 26.34 & - & - \\
\hline 15 & Swine /OPH/Y055-Y056* & 22.53 & - & - \\
\hline 16 & Swine /OPH/YR23-YR24 & 32.32 & - & - \\
\hline AIV (+) duck swab & $\begin{array}{c}\text { Duck/OPH/H11N9 (+) } \\
\text { (A/H11N9/duck/PA/02099/2012) }\end{array}$ & 30.55 & + & + \\
\hline AIV $(+) \mathrm{H} 5 \mathrm{~N} 2$ virus & $\begin{array}{c}\text { AIV H5N2 }\left(10^{3} \mathrm{EID}_{50} / \mathrm{ml}\right)^{\star} \\
(\mathrm{A} / \mathrm{H} 5 \mathrm{~N} 2 / \text { chicken/PA/7659/1985) }\end{array}$ & 30.33 & + & + \\
\hline Negative duck swabs & $\begin{array}{l}\text { Negative wild duck OPH-CS swabs for RNA extraction } \\
\text { control }\end{array}$ & 0 & - & - \\
\hline Negative Swine swabs & $\begin{array}{l}\text { Negative pig OPH swabs for RNA extraction negative } \\
\text { control }\end{array}$ & 0 & - & - \\
\hline
\end{tabular}

Table 1: A summary of the results of Influenza A virus detection for swine oral-pharyngeal (OPH) swab and duck OPH and cloacal swab (CS) samples by real-time RT-PCR (rRT-PCR), conventional RT-PCR (CRT-PCR) and virus isolation. 


\begin{tabular}{|c|c|c|c|c|c|c|c|c|}
\hline \multirow{2}{*}{ Type of swabs and animal ID } & \multirow{2}{*}{$\begin{array}{l}\text { rRT-PCR } \\
\text { Ct-value }\end{array}$} & \multirow{2}{*}{$\begin{array}{l}\text { NGS } \\
\text { total reads }\end{array}$} & \multirow{2}{*}{$\begin{array}{l}\text { Assembled } \\
\text { contigs }\end{array}$} & \multirow{2}{*}{ Unused reads } & \multirow{2}{*}{$\begin{array}{l}\text { Influenza A } \\
\text { virus contigs }\end{array}$} & \multicolumn{3}{|c|}{$\begin{array}{l}\text { Contigs mismatched } \\
\text { to primers and probe }\end{array}$} \\
\hline & & & & & & 3'FP & Pro & 5 'RF \\
\hline Duck/OPH-CS/31477-4 & 22.45 & $2,001,391$ & 1,174 & 222,143 & 0 & 5 & 3 & 4 \\
\hline Duck/OPH-CS/31477-5 & 28.35 & $1,874,558$ & 245 & 345,61 & 0 & 2 & 2 & 3 \\
\hline Duck/OPH-CS/32646-7 & 26.72 & $1,271,086$ & 309 & 85,805 & 0 & 2 & 4 & 6 \\
\hline Swine /OPH/Y047-Y048 & 24.67 & $1,379,134$ & 1,174 & 162,903 & 0 & 2 & 5 & 9 \\
\hline Swine /OPH/Y051-Y052 & 22.74 & $1,979,241$ & 1,802 & 341,676 & 0 & 5 & 4 & 8 \\
\hline Swine /OPH/Y053-Y054 & 26.34 & $1,441,454$ & 1,071 & 208,290 & 0 & 5 & 6 & 8 \\
\hline Swine /OPH/Y055-Y056 & 22.53 & $1,855,902$ & 1,255 & 368,201 & 0 & 8 & 3 & 5 \\
\hline $\begin{array}{l}\text { AIV H5N2, } 10^{3} \mathrm{EID}_{50} / \mathrm{ml}(\mathrm{A} / \mathrm{H} 5 \mathrm{~N} 2 / \\
\text { chicken/PA/7659/1985) }\end{array}$ & 30.33 & $1,158,024$ & 1,398 & 325,748 & 8 & 2 & 1 & 3 \\
\hline $\begin{array}{l}\text { Duck/OPH/H11N9 (+) } \\
\text { (A/H11N9/duck/PA/02099/2012) }\end{array}$ & 30.55 & $1,578,432$ & 190 & 628,782 & 8 & 1 & 1 & 2 \\
\hline Negative SPF chicken swabs & 0 & $1,707,525$ & 259 & 81,517 & 0 & 0 & 0 & 0 \\
\hline
\end{tabular}

Note: FP=Forward Primer; RP=Reverse Primer; Pro=Probe

Table 2: Summary of the results of Influenza A virus detection by next-generation sequencing (NGS) of swine and duck swab samples. All the swabs tested positive for the influenza A virus matrix gene by real-time RT-PCR (rRT-PCR) but negative by conventional gel RT-PCR (cRT-PCR) and virus isolation (VI).

the Illumina MiSeq system [42]. Viral RNAs that were extracted from duck and swine swab samples for rRT-PCR and cRT-PCR were used for NGS. Procedures for sequencing, viral genome assembly, obtaining 5' and 3 ' termini, and sequence analyses were as previously described [43].

\section{Results}

\section{Influenza $A$ virus detection in wild duck and swine swabs by rRT-PCR, cRT-PCR and VI}

Nine wild duck oral-pharyngeal (OPH) and cloacal swab pooled samples (one pool per duck) and seven swine OPH swab pooled samples (one pool per two pigs) tested positive for the influenza A virus by rRT-PCR but tested negative by both cRT-PCR and VI (Table 1).

\section{rRT-PCR result validation}

To validate the rRT-PCR results, first, the rRT-PCR products were analyzed by gel electrophoresis, and clear PCR bands were obtained at approximately $100 \mathrm{bp}$; and second, the Ct-values were analyzed using the ABI real-time PCR program, which confirmed that the Ct-values were technically valid (Figure 1). These results indicated that the Ctvalues of these swab samples represented true reactions that occurred during the rRT-PCR assay.

\section{Influenza A virus detection by NGS}

Four swine swab pooled and three wild duck swab pooled samples that showed strong positive results (Ct-values of 22-28) for the Influenza A virus matrix gene by rRT-PCR were selected for whole genome sequencing using NGS with the Illumina MiSeq System. Our sequencing results revealed that none of the samples contained Influenza A virus contigs; instead, they all contained mismatched contigs of multiple non-specific sequences that partially matched to the rRT-PCR primer and probe sequences (Table 2). The two AIV positive samples $\mathrm{H} 5 \mathrm{~N} 2$ and H11N9 yielded 1.1 million and 1.5 millions of NGS total reads, respectively and each of the swab test samples yielded about 1.2 to 2.0 millions of NGS total reads (Table 2), which were sufficient number of MiSeq reads per sample to detect viral sequences. Furthermore, the mismatched contigs were derived from host cells and other microorganisms contained in the swab samples and thus led to false-positive rRT-PCR reactions (Tables 3 and 4). These genome sequence findings provide scientific evidence that the rRT-PCR false positives were caused by non-specific contig sequences and not by the target viral RNA. The whole genomes of the two positive control samples (an H11N9 positive duck OPH swab pool and H5N2 AIV) were sequenced successfully and matched correctly to their subtypes (Tables 2 and 5).

\section{Discussion}

In the present study, we have investigated three duck and four swine swab pooled samples that tested positive for the influenza A virus by rRT-PCR but tested negative by VI and cRT-PCR. We processed these swab samples for genome sequencing analysis by NGS, and we confirmed that the rRT-PCR positive results were false positive reactions induced by background, non-target RNAs contained in the swab samples. The NGS data identified the non-target RNAs and their segments of identical bases that match to corresponding segments of the rRT-PCR primers and probe. Furthermore, the multiple non-target contigs, or RNA segments, in each swab sample were able to make a perfect match, similar to the target virus contigs, with the whole primer and probe sequences, thus resulting in true PCR reactions that represented false positives. This is a novel methodology of obtaining genome sequence evidence to confirm false positive results generated by rRT-PCR. Therefore, the common interpretation of positive $\mathrm{rRT}$ PCR results for target viral RNA accompanied by negative VI results that this represents the presence of non-viable viruses-could be wrong.

As we know that the USDA AI rRT-PCR assay used in this study was well validated to be $100 \%$ specificity for domestic poultry samples. However, this rRT-PCR assay or other rRT-PCR assays could be subject to non-specific reactions when they were used to test wildlife samples, because wildlife samples contain much complicated microorganisms or exotic/unknown molecular substances which may interference the rRT-PCR reactions. Thus, it is not surprising we obtained false rRTPCR positive results of the wild duck and swine swab samples in this study, and similar results of other published studies as discussed below.

A published study of AIV detection in wild birds reported that 97 of the 137 birds (70.8\%) tested positive for AIV by rRT-PCR using cloacal and/or OPH swabs, but only nine of the 137 birds (6.6\%) tested positive for AIV by VI. Thus, we know that at least 88 (97 to 9), or $90.72 \%$, of the rRT-PCR-positive samples failed in the AIV isolation; these samples should not be misinterpreted as being positive for AIV RNA, because they could in reality be rRT-PCR false positives. Another excellent report of AIV surveillance in wild birds in Georgia (conducted between 2009 and 2011 and published by Lewis et al. in 
Citation: Lu H, Tang Y, Lin L, Wolfgang DR (2016) Next-Generation Sequencing Confirmation of Real-Time RT-PCR False Positive Influenza-A Virus Detection in Waterfowl and Swine Swab Samples. Next Generat Sequenc \& Applic 3: 134. doi:10.4172/2469-9853.1000134

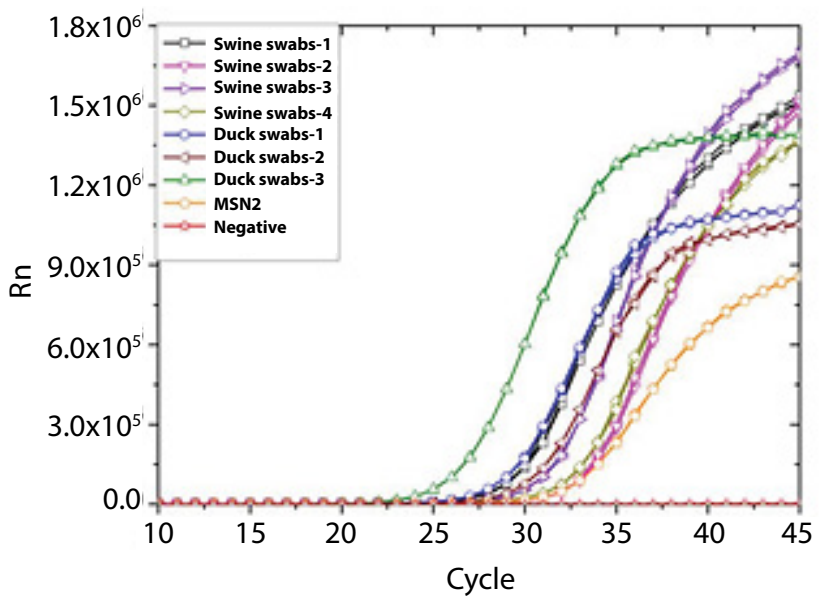

Figure 1: The Ct-value curves of the swine and duck swab samples that tested positive for the influenza A virus matrix gene by real-time RT-PCR (rRT-PCR).

\begin{tabular}{|c|c|c|c|c|c|c|c|c|c|c|c|}
\hline \multirow{2}{*}{$\begin{array}{l}\text { Detected contig } \\
\text { ID }\end{array}$} & \multicolumn{8}{|c|}{ Matched contig sequence bases by next-generation sequencing } & \multirow{3}{*}{$\begin{array}{l}\text { Average } \\
\text { coverage }\end{array}$} & \multirow{3}{*}{ Contig origin } & \multirow{3}{*}{$\begin{array}{c}\text { GenBank } \\
\text { Accession\# }\end{array}$} \\
\hline & \multicolumn{8}{|c|}{ (1) Duck/OPH-CS/31477-4, Ct=22.45 } & & & \\
\hline 3' F-Primer & AGA & TGA & GTC & TTC & TAA & CCG & AGG & TCG & & & \\
\hline Contig0525 & AGA & TGA & GTC & TTC & TA & & & & 3.49 & Bacteria & DQ207481 \\
\hline Contig0209 & & & $\mathrm{C}$ & TTC & TAA & CCG & TGG & $\mathrm{T}$ & 11.08 & Bacteria & СР010368 \\
\hline Contig0295 & AGA & TGA & GTC & $\mathrm{T}$ & & & & & 19.51 & rRNA & NR_076702 \\
\hline Contig0205 & GA & TGA & GTC & $\mathrm{TT}$ & & & & & 23.16 & rRNA & AF202181 \\
\hline Contig0026 & & TGA & GTC & TTC & $\mathrm{T}$ & & & & 295.83 & Bacteria & СР007549 \\
\hline Probe & TCA & GGC & $\mathrm{CCC}$ & CTC & AAA & GCC & GA & & & & \\
\hline Contig0226 & & & $\mathrm{CCC}$ & CTC & AAA & G & & & 107.14 & Duck & KC466567 \\
\hline Contig0183 & & & $\mathrm{C}$ & CTC & AAA & GCC & & & 19.76 & rRNA & NR_076625 \\
\hline Contig0080 & & & & $\mathrm{TC}$ & AAA & GCC & GA & & 211.84 & rRNA & CP007619 \\
\hline 5' R-Primer & TGC & AAA & AAC & ATC & TTC & AAG & TCT & CTG & & & \\
\hline Contig0334 & & $A A$ & AAC & ATC & TTC & & & & 7.99 & Unknown & \\
\hline Contig0139 & & A & AAC & ATC & TTC & AAG & $\mathrm{T}$ & & 10.66 & Bacteria & AP014630 \\
\hline Contig0312 & & & AAC & ATC & TTC & A & & & 9.65 & Unknown & \\
\hline \multirow[t]{2}{*}{ Contig0269 } & & AAA & AAC & ATC & $\mathrm{T}$ & & & & 19.66 & rRNA & AY245110 \\
\hline & \multicolumn{8}{|c|}{ (2) Duck/OPH-CS/31477-5, Ct=28.35 } & & & \\
\hline 3' F-Primer & AGA & TGA & GTC & TTC & TAA & CCG & AGG & TCG & & & \\
\hline Contig0004 & G & ATG & AGT & CTT & $\mathrm{CT}$ & & & & 159.22 & Phage & KC352403 \\
\hline Contig0073 & G & ATG & AGT & CTT & & & & & 2.22 & rRNA & JN935869 \\
\hline Probe & TCA & GGC & $\mathrm{CCC}$ & CTC & AAA & GCC & GA & & & & \\
\hline Contig0135 & $\mathrm{CA}$ & GCC & $\mathrm{CCC}$ & CTC & AAA & & & & 81.39 & Bacteria & СР007410 \\
\hline Contig0006 & & & $\mathrm{CCC}$ & СTC & AAA & G & & & 834.82 & Duck & KJ833587 \\
\hline 5' R-Primer & TGC & AAA & $A A C$ & ATC & TTC & AAG & TCT & CTG & & & \\
\hline Contig0198 & & & $A C$ & ATC & TTC & $A A$ & & & 4.35 & Duck & XM_5027579 \\
\hline Contig0023 & & & $\mathrm{AC}$ & ATC & TTC & AA & & & 36.79 & Unknown & \\
\hline \multirow[t]{2}{*}{ Contig002 } & & & C & ATC & TTC & AAG & & & 7.85 & Bacteria & СР007766 \\
\hline & \multicolumn{8}{|c|}{ (3) Duck/OPH-CS/32646-7, Ct=26.72 } & & & \\
\hline 3' F-Primer & AGA & TGA & GTC & TTC & TAA & CCG & AGG & TCG & & & \\
\hline Contig0282 & AGA & TGA & GTC & $\mathrm{TT}$ & & & & & 2.84 & rRNA & NR_103040 \\
\hline Contig0055 & & TGA & GTC & TTC & $\mathrm{T}$ & & & & 86.81 & Bacteria & СР007549 \\
\hline Probe & TCA & GGC & $\mathrm{CCC}$ & CTC & AAA & GCC & GA & & & & \\
\hline
\end{tabular}




\begin{tabular}{|c|c|c|c|c|c|c|c|c|c|c|c|}
\hline Contig0296 & & & $\mathrm{CCC}$ & CTC & AAA & GCC & & & 8.45 & Duck & XM_5020670 \\
\hline Contig0132 & TCA & GGC & $\mathrm{CCC}$ & CTC & AAA & & & & 182.02 & rRNA & СР006649 \\
\hline Contig0127 & & GGC & $\mathrm{CCC}$ & CTC & A & & & & 51.39 & Bacteria & СР008921 \\
\hline Contig0017 & & & $\mathrm{CCC}$ & CTC & AAA & G & & & 815.69 & Duck & KJ833587 \\
\hline 5' R-Primer & TGC & AAA & AAC & ATC & TTC & AAG & TCT & CTG & & & \\
\hline Contig0309 & & & C & ATC & TTC & AAG & & & 1.86 & Duck & XM_5017337 \\
\hline Contig0271 & $\mathrm{C}$ & AAA & AAC & ATC & & & & & 3.39 & Duck & KC466567 \\
\hline Contig0193 & & & & & $\mathrm{TC}$ & AAG & TCT & CT & 18.91 & $r R N A$ & HQ402849 \\
\hline Contig0077 & & & $\mathrm{AC}$ & ATC & TTC & $\mathrm{AA}$ & & & 1145.11 & rRNA & GU323337 \\
\hline Contig0067 & & & $A C$ & ATC & TTC & $\mathrm{AA}$ & & & 547.63 & rRNA & AB303970 \\
\hline Contig0045 & & & $A C$ & ATC & TTC & $\mathrm{AA}$ & & & 410.67 & Bacteria & СР010307 \\
\hline
\end{tabular}

Table 3: The results of Influenza A virus detection by next-generation sequencing (NGS) of duck swab samples (pool of oral-pharyngeal (OPH) swabs and cloacal swabs per duck). All of the duck swab pools tested positive for the Influenza A virus by real-time RT-PCR (rRT-PCR) but negative by conventional gel RT-PCR (cRT-PCR) and virus isolation.

PLoS One) described detailed studies and the results of tests using first rRT-PCR and subsequently VI for rRT-PCR-positive samples to detect AIV in fresh faecal, cloacal or tracheal samples from various waterfowl species [40]. Only 23 out of 84 rRT-PCR-positive swab samples (27\%) were positive for AIV isolation. Of the 23 VI-positive samples, 20 showed strong rRT-PCR results (Ct-values of 16.69 to 29.99), and the remaining three were weakly positive (Ct-values of 30.00 to 33.96). Of the 60 samples that tested negative by VI but positive by rRT-PCR, 27 showed strong rRT-PCR positive results (Ct-values of 17.89 to 29.99), and 33 showed weak positive results (Ct-values of 30.00 to 39.38 ). The authors' declaration that "We were generally successful in isolating virus from M RRT-PCR positive samples with a CT-value of under 30 is applicable to the $23 \mathrm{VI}$-positive samples ( 20 with Ct-values under 30 and 3 with Ct-values above 30 ) but cannot explain the 27 VI-negative samples with strong rRT-PCR positive results (Ct-values under 30 ). Furthermore, among the 23 AIV isolates, 11 were obtained from duck samples and 12 were obtained from gull samples; thus, we cannot agree with the following assumption made by the author: "However we also note that we appeared somewhat more unsuccessful isolating virus from low CT-value samples if they were taken from gulls rather than ducks. This might indicate that some influenza A viruses in gulls do not optimally replicate to high titers in our current culture and isolation system". Interpretations such as these are speculative and not based on scientific evidence. Another report of AIV surveillance in wild birds reported that 332 virus isolates were recovered from 992 rRTPCR-positive samples, representing an overall recovery rate of $33.5 \%$ (332/992) and a VI failure rate of $66.5 \%$ [37]. In fact, the majority of the rRT-PCR-positive samples that failed in VI appear to be either true negatives or rRT-PCR false positives. Our research findings using NGS for the identification of rRT-PCR false positive results in the present study provide a new approach and interpretation based on scientific evidence for the confirmation of rRT-PCR false positive results.

The rRT-PCR product amplified by the primers and probe for the influenza A virus $\mathrm{M}$ gene is only $95 \mathrm{bp}$ long, as determined by the difference between the forward 3'-25+ primer (5-25) and the reverse 5'-124 primer (76-99), which is appropriate for the rapid collection of amplicon signals during rRT-PCR reactions, but which may be easily subject to cross-reaction with non-target RNAs [27]. In contrast, the duck and swine swab samples in our report tested negative for the influenza A virus by cRT-PCR, indicating the cRT-PCR reactions were not affected by the non-target RNA sequences in the samples, or some related factors we need to investigate. Nonetheless, cRTPCR appears having an advantage over rRT-PCR in its ability to eliminate such false positive results and thus could be used as an alternative approach for confirming rRT-PCR false positive results in swab samples.

On the other hand, influenza surveillance field samples that tested positive by rRT-PCR and negative by VI can be due to dead virus and/or extremely low virus titers in the samples or a new field variant strain that is not feasible in VI. Although these possibilities are not easy to confirm or rule out in general, alternatively, testing additional collections of the same source samples are more practical in monitoring influenza virus true status.

The confirmation of the rRT-PCR false positive results for influenza A virus detection in this study indicates that it is important and necessary to maintain VI as the "gold standard" for influenza A virus surveillance, despite the availability of advanced molecular assays. It is especially important to use VI to acquire accurate results when conducting Influenza, A virus surveillance in field samples obtained from complicated background sources, when a high rate of non-specific RNA cross contamination is likely, or from clinically healthy animals. Conversely, it is clear that the influenza A virus rRT-PCR assay is more suitable and accurate for the testing of laboratory samples or relatively clean swab (e.g. tracheal swab) samples than in the testing of dirty samples (e.g. cloacal or faecal swabs) or complicated source samples of wildlife species. In fact, most field samples, especially wildlife samples, contain complicated background substances including a large number of unidentified host mRNAs or mutated viral RNAs that can easily produce false positive results. The wild duck and swine swab pooled samples used in the present study are good examples of animal swabs that are not suitable to be called truly positive for Influenza A based only on rRT-PCR testing. Additionally, the classic VI technique remains useful for detecting unexpected, unknown and unforeseen viruses, as well as for identifying entirely new viral agents; therefore, VI remains the "gold standard" and may continue to do so in the future.

NGS is a powerful high-throughput sequencing methodology that generates millions of sequencing reads and can directly sequence viral RNAs. NGS methodologies have revolutionized the detection of emerging variants and novel or unknown viruses that are beyond the capabilities of the VI method. As the most powerful genome 
Citation: Lu H, Tang Y, Lin L, Wolfgang DR (2016) Next-Generation Sequencing Confirmation of Real-Time RT-PCR False Positive Influenza-A Virus Detection in Waterfowl and Swine Swab Samples. Next Generat Sequenc \& Applic 3: 134. doi:10.4172/2469-9853.1000134

Page 6 of 9

\begin{tabular}{|c|c|c|c|c|c|c|c|c|c|c|c|}
\hline \multirow{2}{*}{ Detected contig ID } & \multicolumn{8}{|c|}{ Matched contig sequence bases by next-generation sequencing } & \multirow{3}{*}{$\begin{array}{l}\text { Average } \\
\text { coverage }\end{array}$} & \multirow{3}{*}{ Contig origin } & \multirow{3}{*}{$\begin{array}{l}\text { GenBank } \\
\text { Accession }\end{array}$} \\
\hline & \multicolumn{8}{|c|}{ (1) Swine $/ \mathrm{OPH} / \mathrm{Y} 055-\mathrm{Y} 056, \mathrm{Ct}=22.53$} & & & \\
\hline 3' F-primer & AGA & TGA & GTC & TTC & TAA & CCG & AGG & TCG & & & \\
\hline Contig1217 & & & GTC & TTC & TAA & C & & & 2.61 & Bacteria & CP001650 \\
\hline Contig0903 & AGA & TGA & GTC & $\mathrm{T}$ & & & & & 4.44 & Bacteria & CP002696 \\
\hline Contig0796 & GA & TGA & GTC & TT & & & & & 3.32 & rRNA & KC249997 \\
\hline Contig0792 & GA & TGA & GTC & TT & & & & & 9.52 & rRNA & JQ311014 \\
\hline Contig0301 & & TGA & GTC & TTC & $\mathrm{T}$ & & & & 4.61 & Unknown & \\
\hline Contig0253 & GA & TGA & GTC & TT & & & & & 23.55 & rRNA & AF202181 \\
\hline Contig0182 & & & C & TTC & TAA & CCG & & & 441.35 & Bacteria & CP000764 \\
\hline Contig0027 & & TGA & GTC & TTC & $\mathrm{T}$ & & & & 138.03 & Bacteria & LM997153 \\
\hline Probe & TCA & GGC & $\mathrm{CcC}$ & CTC & AAA & GCC & GA & & & & \\
\hline Contig1037 & & & & TC & AAA & GCC & GA & & 2.51 & Swine & KJ746666 \\
\hline Contig0800 & TCA & GGC & $\mathrm{CCC}$ & C & & & & & 16.43 & rRNA & NR076498 \\
\hline Contig0258 & & & & TC & AAA & GCC & $\mathrm{GA}$ & & 150.77 & rRNA & NR121978 \\
\hline 5'R-Primer & TGC & AAA & AAC & ATC & TTC & AAG & TCT & CTG & & & \\
\hline Contig1061 & & A & AAC & ATC & TTC & AA & & & 11.07 & Unknown & \\
\hline Contig1218 & & & & TC & TTC & AAG & TCT & & 2.47 & Unknown & \\
\hline Contig0147 & & A & AAC & ATC & TTC & A & & & 1686.85 & rRNA & FJ498886 \\
\hline Contig0798 & TGC & AAA & AAC & ATC & $\mathrm{T}$ & & & & 4.72 & Unknown & \\
\hline Contig0765 & & & & ATC & TTC & AAG & TGT & C & 42.29 & rRNA & AJ542473 \\
\hline Contig1107 & & A & AAC & ATC & TTC & & & & 2.90 & Bacteria & СР003040 \\
\hline Contig1002 & & & $\mathrm{C}$ & ATC & TTC & AAG & & & 2.45 & Bacteria & AP012044 \\
\hline Contig0835 & C & AAA & AAC & ATC & & & & & 3.56 & Unknown & \\
\hline Contig0830 & & & AAC & ATC & TTC & A & & & 3.67 & Unknown & \\
\hline Contig0356 & & A & AAC & ATC & TTC & & & & 5.05 & rRNA & NR_076582 \\
\hline Contig0353 & C & AAA & AAC & ATC & & & & & 37.34 & Swine & KF569218 \\
\hline Contig0267 & & & $A C$ & ATC & TTC & AA & & & 186.58 & rRNA & NR_121978 \\
\hline \multirow[t]{2}{*}{ Contig0108 } & & & AAC & ATC & TTC & A & & & 6.54 & Unknown & \\
\hline & \multicolumn{8}{|c|}{ (2) Swine /OPH/Y053-Y054, Ct=26.34 } & & & \\
\hline 3' F-Primer & AGA & TGA & GTC & TTC & TAA & CCG & AGG & TCG & & & \\
\hline Contig0035 & & A & GTC & TTC & TAA & CCG & & & 760.61 & rRNA & NR_121989 \\
\hline Contig0892 & AGA & TGA & GTC & $T$ & & & & & 3.64 & Bacteria & СР002696 \\
\hline Contig0409 & GA & TGA & GTC & TT & & & & & 14.53 & rRNA & JQ034423 \\
\hline Contig0097 & & TGA & GTC & TTC & $T$ & & & & 152.61 & Trematoda & LL266921 \\
\hline Contig0092 & & & C & TTC & TAA & CCG & & & 420.54 & Bacteria & СР005586 \\
\hline Probe & TCA & GGC & $\mathrm{CcC}$ & СТC & AAA & GCC & GA & & & & \\
\hline Contig0013 & TCA & GGC & $\mathrm{CCC}$ & CT & & & & & 145.3 & rRNA & JQ337010 \\
\hline Contig0923 & & & $\mathrm{CC}$ & CTC & AAA & GCC & GA & & 3.08 & rRNA & NR_103206 \\
\hline Contig0764 & TCA & GGC & $\mathrm{CcC}$ & C & & & & & 21.39 & rRNA & GQ877606 \\
\hline Contig0590 & & & & TC & AAA & GCC & GA & & 97.68 & Bacteria & CP010896 \\
\hline Contig0477 & & & C & CTC & AAA & GCC & & & 10.55 & Bacteria & KC246835 \\
\hline Contig0012 & & & $\mathrm{CcC}$ & CTC & AAA & G & & & 9173.2 & rRNA & NR_076885 \\
\hline 5' R-Primer & TGC & AAA & AAC & ATC & TTC & AAG & TCT & CTG & & & \\
\hline Contig0913 & TGC & AAA & AAC & ATC & TTC & AA & & & 1.59 & Bacteria & CP007208 \\
\hline Contig0518 & & A & AAC & ATC & TTC & AA & & & 45.94 & Bacteria & AM295250 \\
\hline Contig0827 & C & AAA & AAC & ATC & & & & & 8.77 & Swine & JN601068 \\
\hline Contig0778 & & & AAC & ATC & TTC & A & & & 2.11 & Unknown & \\
\hline Contig0707 & & & AAC & ATC & TTC & A & & & 2.06 & Unknown & \\
\hline Contig0185 & & & $A C$ & ATC & TTC & AA & & & 174.61 & rRNA & GU926746 \\
\hline Contig0044 & & A & AAC & ATC & TTC & & & & 156.42 & rRNA & EU778531 \\
\hline \multirow[t]{2}{*}{ Contig0008 } & & & & TC & TTC & AAG & TC & & 168.3 & rRNA & NR_076878 \\
\hline & \multicolumn{8}{|c|}{ (3) Swine/OPH/Y051-Y052, Ct=22.74 } & & & \\
\hline 3' F-Primer & AGA & TGA & GTC & TTC & TAA & CCG & AGG & TCG & & & \\
\hline Contig0810 & GA & TGA & GTC & TT & & & & & 27.62 & rRNA & AY305327 \\
\hline Contig0851 & & $A$ & GTC & TTC & TAA & C & & & 4.99 & Por.Para.Flu & JX857409 \\
\hline Contig0650 & GA & TGA & GTC & TT & & & & & 3.58 & rRNA & AF202181 \\
\hline Contig0138 & & TGA & GTC & TTC & $\mathrm{T}$ & & & & 149.69 & Trematoda & LL266921 \\
\hline Contig0111 & & & C & TTC & TAA & CCG & & & 1224.61 & rRNA & FO681347 \\
\hline Probe & TCA & GGC & $\mathrm{ccc}$ & CTC & AAA & GCC & GA & & 1328.37 & rRNA & EU066039 \\
\hline Contig0301 & TCA & GAC & $\mathrm{CcC}$ & CTC & AAA & & & & & & \\
\hline
\end{tabular}


Citation: Lu H, Tang Y, Lin L, Wolfgang DR (2016) Next-Generation Sequencing Confirmation of Real-Time RT-PCR False Positive Influenza-A Virus Detection in Waterfowl and Swine Swab Samples. Next Generat Sequenc \& Applic 3: 134. doi:10.4172/2469-9853.1000134

Page 7 of 9

\begin{tabular}{|c|c|c|c|c|c|c|c|c|c|c|c|}
\hline Contig1113 & TCA & GGC & $\mathrm{CCC}$ & СтC & AA & & & & 37.16 & rRNA & NR_076498 \\
\hline Contig0619 & TCA & GGC & CCC & C & & & & & 445.77 & rRNA & NR_076128 \\
\hline Contig0172 & A & GGC & $\mathrm{CCC}$ & СтC & & & & & 443.03 & rRNA & HM545299 \\
\hline 5' R-Primer & TGC & AAA & AAC & ATC & TTC & AAG & TCT & CTG & & & \\
\hline Contig0885 & & A & AAC & ATC & TTC & AA & & & 17.59 & Bacteria & FR695868 \\
\hline Contig0827 & TGC & AAA & AAC & ATC & TTC & AAG & TCT & CTG & 2.25 & Unknown & \\
\hline Contig0900 & & & AAC & ATC & TTC & A & & & 14.96 & Unknown & \\
\hline Contig0843 & & AAA & AAC & ATC & $T$ & & & & 42.68 & rRNA & JX515400 \\
\hline Contig0723 & & & C & ATC & TTC & AAG & & & 57.35 & rRNA & X67761 \\
\hline Contig0694 & C & AAA & AAC & ATC & & & & & 20.85 & rRNA & 4V19_A \\
\hline Contig0161 & & & & ATC & TTC & AAG & TGT & C & 2733.7 & rRNA & NR_076295 \\
\hline \multirow[t]{2}{*}{ Contig1167 } & & & AC & ATC & TTC & AA & & & 288.84 & Unknown & \\
\hline & \multicolumn{8}{|c|}{ (4) Swine/OPH/Y047-Y048, Ct=24.67 } & & & \\
\hline 3' F-Primer & AGA & TGA & GTC & TTC & TAA & CCG & AGG & TCG & & & \\
\hline Contig231 & & & & C & TAA & CCG & AGG & & 233.37 & Bacteria & СР002631 \\
\hline Contig80 & & TGA & GTC & TTC & $T$ & & & & 227.46 & Bacteria & СР004084 \\
\hline Probe & TCA & GGC & $\mathrm{CCC}$ & CTC & AAA & GCC & GA & & & & \\
\hline Contig0716 & TCA & GGC & $\mathrm{CcC}$ & CT & & & & & 24.47 & rRNA & JX635010 \\
\hline Contig0505 & TCA & GGC & $\mathrm{CCC}$ & СтC & AAA & & & & 41.85 & rRNA & JX638985 \\
\hline Contig0592 & & & & TC & AAA & GCC & GA & & 87.03 & Bacteria & AM181176 \\
\hline Contig0545 & & & & TC & AAA & GCC & GA & & 66.60 & Bacteria & EU063768 \\
\hline Contig0359 & & & & TC & AAA & GCC & GA & & 257.15 & rRNA & GQ876410 \\
\hline 5' R-Primer & TGC & AAA & AAC & ATC & TTC & AAG & TCT & CTG & & & \\
\hline Contig0763 & & A & AAC & ATC & TTC & $\mathrm{AA}$ & & & 15.2 & Bacteria & FJ872373 \\
\hline Contig1110 & & & C & ATC & TTC & AAG & TCT & CTG & 2.62 & Unknown & \\
\hline Contig0776 & & & & ATC & TTC & AAG & TGT & C & 52.36 & rRNA & NR_076295 \\
\hline Contig0535 & TGC & AAA & AAC & A & & & & & 77.42 & Bacteria & FN668375 \\
\hline Contig0418 & TGC & AAA & AAC & A & & & & & 132.61 & rRNA & NR_121991 \\
\hline Contig0283 & & A & AAC & ATC & TTC & & & & 531.11 & rRNA & EU778531 \\
\hline Contig0249 & & & $\mathrm{C}$ & ATC & TTC & AAG & & & 63.01 & Bacteria & СР006809 \\
\hline Contig0205 & & & C & ATC & TTC & AAG & & & 201.79 & Bacteria & СР006772 \\
\hline Contig0060 & & & AC & ATC & TTC & AA & & & 289.82 & rRNA & NR_121995 \\
\hline
\end{tabular}

Table 4: The results of Influenza A virus detection by next-generation sequencing (NGS) for swine swabs (two pig oral-pharyngeal (OPH) swabs pooled for each swab sample for the NGS test). Each of these swine swabs individually tested positive for the Influenza A virus by real-time RT-PCR (rRT-PCR) but negative by conventional gel RT-PCR (CRT-PCR) and virus isolation.

\begin{tabular}{|c|c|c|c|c|c|c|c|c|c|c|c|}
\hline \multirow{3}{*}{$\begin{array}{c}\text { Detected contig ID } \\
\text { 3' F-Primer }\end{array}$} & \multicolumn{8}{|c|}{ Matched contig sequence bases by next-generation sequencing } & \multirow{3}{*}{$\begin{array}{l}\text { Average } \\
\text { coverage }\end{array}$} & \multirow{3}{*}{ Contig origin } & \multirow{3}{*}{$\begin{array}{c}\text { GenBank } \\
\text { Accession\# }\end{array}$} \\
\hline & \multicolumn{8}{|c|}{ AIV H5N2 $\left(10^{3} \mathrm{EID}_{50} / \mathrm{ml}\right), \mathrm{Ct}=30.33$} & & & \\
\hline & AGA & TGA & GTC & TTC & TAA & CCG & AGG & TCG & & & \\
\hline Contig0269 & AGA & TGA & GTC & TTC & TAA & CCG & AGG & TCG & 576.51 & Influenza A & KP674444 \\
\hline Contig0987 & & & & & AA & CCG & AGG & TC & 3.37 & Chicken & BX931775 \\
\hline Probe & TCA & GGC & $\mathrm{CCC}$ & CTC & AAA & GCC & GA & & & & \\
\hline Contig0269 & TCA & GGC & $\mathrm{CCC}$ & CTC & AAA & GCC & GA & & 576.51 & Influenza A & KP674444 \\
\hline 5' R-Primer & TGC & AAA & AAC & ATC & TTC & AAG & TCT & CTG & & & \\
\hline Contig0269 & TGC & AAA & AAC & ATC & TTC & AAG & TCT & CTG & 576.51 & Influenza A & KP674444 \\
\hline Contig0691 & & & & $\mathrm{TC}$ & TTC & AAG & TC & & 6.46 & Unknown & \\
\hline \multirow[t]{2}{*}{ Contig0563 } & & & & & $\mathrm{C}$ & AAG & TCT & CTG & & Chicken & XR_214244 \\
\hline & \multicolumn{8}{|c|}{ H11N9 positive duck OPH swabs, $\mathrm{Ct}=30.55$} & & & \\
\hline 3' F-Primer & AGA & TGA & GTC & TTC & TAA & CCG & AGG & TCG & & & \\
\hline Contig086 & AGA & TGA & GTC & TTC & TAA & CCG & AGG & TCG & 17.7 & Influenza A & CY149605 \\
\hline Probe & TCA & GGC & $\mathrm{CCC}$ & CTC & AAA & GCC & GA & & & & \\
\hline Contig086 & TCA & GGC & $\mathrm{CCC}$ & CTC & AAA & GCC & GA & & 17.7 & Influenza A & CY149605 \\
\hline Contig147 & & & $\mathrm{C}$ & CTC & AAA & GCC & GA & & 7.08 & Unknown & \\
\hline 3' F-Primer & TGC & AAA & AAC & ATC & TTC & AAG & TCT & CTG & & & \\
\hline Contig086 & TGC & AAA & AAC & ATC & TTC & AAG & TCT & CTG & 17.7 & Influenza A & CY149605 \\
\hline
\end{tabular}

Table 5: The results of Influenza A virus detection by next-generation sequencing (NGS) for two positive control Influenza A viruses of the low pathogenic avian influenza virus (LPAIV) H5N2 subtype (A/chicken/PA/7659/1985, GenBank Accession No. KP674444-KP674451) and H11N9 subtype (A/duck/PA/02099/2012, GenBank Accession No. KR870234-KR870241), propagated in SPF embryonating chicken eggs. 
Citation: Lu H, Tang Y, Lin L, Wolfgang DR (2016) Next-Generation Sequencing Confirmation of Real-Time RT-PCR False Positive Influenza-A Virus Detection in Waterfowl and Swine Swab Samples. Next Generat Sequenc \& Applic 3: 134. doi:10.4172/2469-9853.1000134

sequencing technology, NGS overcomes the limitations of VI and rRT-PCR, as described here, by identifying every sequenceable RNA in each sample and providing direct genome sequence evidence for false positive rRT-PCR reactions caused by mismatching of non-target RNAs to the rRT-PCR primers and probe. In the analysis of the rRTPCR results from seven swine and nine duck swab pooled samples, the Ct-values obtained indicated high "viral RNA" concentrations in these swab samples. However, when seven of the swab samples with strong rRT-PCR positive results (Ct-values of 22-28) were selected for NGS analysis, none of them were found to contain influenza A virus-related contigs. Conversely, the positive control $\mathrm{H} 5 \mathrm{~N} 2$ virus (A/ chicken/PA/7659/1985, $10^{3} \mathrm{EID}_{50} / \mathrm{ml}$ ) and the $\mathrm{H} 11 \mathrm{~N} 9$ positive duck OPH swabs (A/H11N9/duck/PA/02099/2012), both of which yielded a weak positive rRT-PCR result (Ct-value of 30), were fully sequenced and found to contain eight influenza A virus contigs. These NGS results provide the first genome sequence evidence for false positive rRT-PCR results in the detection of influenza A virus in wild duck and swine swab samples.

\section{Acknowledgements}

This research was funded by the Pennsylvania department of agriculture (PDA), the animal health and diagnostic commission (HDC)'s research program, 2014-2015, Pennsylvania, USA.

\section{References}

1. Couch RB (1996) Orthomyxoviruses (Chapter 58). In: Baron S (Ed.) Medica Microbiology (4thedn.), Galveston (TX): University of Texas Medical Branch at Galveston.

2. Baigent SJ, McCauley JW (2003) Influenza type A in humans, mammals and birds: determinants of virus virulence, host-range and interspecies transmission. BioEssays 25: 657-671.

3. Webster RG, Bean WJ, Gorman OT, Chambers TM, Kawaoka Y (1992) Evolution and ecology of influenza A viruses. Microbiol Rev 56: 152-179.

4. Rutz C, Dalessi S, Baumer A, Kestenholz M, Engels M, et al. (2007) Avian influenza: wildbird monitoring in Switzerland between 2003-2006. Schweiz Arch Tierh 149: 501-509.

5. Haider N, Sturm-Ramirez K, Khan SU, Rahman MZ, Sarkar S, et al. (2015) Unusually High Mortality in Waterfowl Caused by Highly Pathogenic Avian Influenza A(H5N1) in Bangladesh. Transbound Emerg Dis.

6. Astorga RJ, Leon L, Cubero MJ, Arenas A, Maldonado A, et al. (1994) Avian influenza in wild waterfowl and shorebirds in the Donana National Park: Serological survey using the enzyme-linked immunosorbent assay. Avian pathol 23: 339-344.

7. Du N, Yang XX, Wang M, Lan Y, Yang L, et al. (2009) Review on the etiological property of the swine influenza virus. Chinese J Virol 25: 39-47.

8. Dunlap MK (1948) Human and swine influenza; A review. Vet Clin N Am 29: 782

9. Wahlgren J (2011) Influenza A viruses: An ecology review. Infect Eco Epidemiol.

10. Tong S, Li Y, Rivailler P, Conrardy C, Castillo DA, et al. (2012) A distinct lineage of influenza A virus from bats. PNAS 109: 4269-4274

11. Tong S, Zhu X, Li Y, Shi M, Zhang J, et al. (2013) New world bats harbor diverse influenza A viruses. Plos Pathog 9: e1003657.

12. Suarez DL, Das A, Ellis E (2007) Review of rapid molecular diagnostic tools for avian influenza virus. Avian Dis 51: 201-208.

13. Peacey M, Hall RJ, Bocacao J, Huang QS (2009) Diagnostic assay recommended by the world health organization for swine origin influenza a $(\mathrm{H} 1 \mathrm{~N} 1)$ virus cross-reacts with H5N1 influenza virus. J Clin Microbiol 47 3789-3790.

14. Cappucci DT Jr, Johnson DC, Brugh M, Smith TM, Jackson CF, et al. (1985) Isolation of avian influenza virus (subtype H5N2) from chicken eggs during a natural outbreak. Avian Dis 29: 1195-1200.

15. Edwards S (2006) OIE laboratory standards for avian influenza. Deve Biologicals 124: 159-162.
16. Zowalaty El, Abin ME, Chander M, Redig Y, Goyal SM, et al. (2011) Improved method for the isolation and sub-typing of avian influenza viruses from oropharyngeal samples of ducks. Avian Dis 55: 439-442.

17. Ferguson NM, Cummings DA, Cauchemez S, Fraser C, Riley S, et al. (2005) Strategies for containing an emerging influenza pandemic in Southeast Asia. Nature 437: 209-214

18. Olsen B, Munster VJ, Wallensten A, Waldenström J, Osterhaus AD, et al (2006) Global patterns of influenza A virus in wild birds. Science 312: $384-388$

19. Zhang A, Jin M, Liu FF, Guo X, Hu Q, et al. (2006) Development and evaluation of a DAS-ELISA for rapid detection of avian influenza viruses. Avian Dis 50: 325-330.

20. Lu H (2003) A longitudinal study of a novel dot-enzyme-linked immunosorbent assay for detection of avian influenza virus. Avian Dis 47: 361-369.

21. Koskinen JO, Vainionpaa R, Meltola NJ, Soukka J, Hanninen PE, et al. (2007) Rapid method for detection of influenza $A$ and $B$ virus antigens by use of a two photon excitation assay technique and dry-chemistry reagents. J Clin Microbio 45: 3581-3588.

22. Ho HT, Qian HL, He F, Meng T, Szyporta M, et al. (2009) Rapid detection of $\mathrm{H} 5 \mathrm{~N} 1$ subtype influenza viruses by antigen capture enzyme-linked immunosorbent assay using $\mathrm{H} 5$-and $\mathrm{N} 1$-specific monoclonal antibodies. Clin Vaccine Immunol 16: 726-732.

23. Starick E, Romer-Oberdorfer A, Werner O (2000) Type- and subtype-specific RT-PCR assays for avian influenza A viruses (AIV). J Vet Med B Infect Dis Vet Public Health 47: 295-301.

24. Lee MS, Chang PC, Shien JH, Cheng MC, Shieh HK (2001) Identification and subtyping of avian influenza viruses by reverse transcription-PCR. J Virol Methods 97: 13-22.

25. Lu H, Xie Z, Liu J, Lin L (2013) Studies on Multiplex RT-PCR for Detection of Avian Influenza Virus Type A Group and Specific H5 and H7 Subtypes. J Veter Sci Med 2: 5.

26. Chaharaein B, Omar A, Aini I, Yusoff K, Hassan S (2009) Detection of H5, H7 and $\mathrm{H} 9$ subtypes of avian influenza viruses by multiplex reverse transcriptionpolymerase chain reaction. Microbiol Res 164: 174-179.

27. Spackman E, Senne DA, Myers TJ, Bulaga LL, Garber LP, et al. (2002 Development of a real-time reverse transcriptase PCR assay for type A influenza virus and the avian $\mathrm{H} 5$ and $\mathrm{H} 7$ hemagglutinin subtypes. $\mathrm{J}$ Clin Microbiol 40: 3256-3260.

28. Hoffmann B, Harder T, Starick E, Depner K, Werner O, et al. (2007) Rapid and highly sensitive pathotyping of avian influenza $A$ H5N1 virus by using real-time reverse transcription-PCR. J Clin Microbiol 45: 600-603.

29. Soheili Z and Samiei S (2005) Real time PCR: principles and application. Hepa Mon 5: 83-87.

30. Imai M, Ninomiya A, Minekawa H, Notomi T, Ishizaki T, et al. (2006) Development of H5-RT-LAMP (loop-mediated isothermal amplification) system for rapid diagnosis of $\mathrm{H} 5$ avian influenza virus infection. Vaccine 24: 6679-6682.

31. Teifke JP, Klopfleisch R, Globig A, Starick E, Hoffmann B, et al. (2007) Pathology of natural infections by H5N1 highly pathogenic avian influenza virus in mute (Cygnus olor) and whooper (Cygnus cygnus) swans. Vet Patho 44: 137-143.

32. Niesters HG (2001) Quantitation of viral load using real-time amplification techniques. Methods 25: 419-429.

33. Kubista M, Andrade JM, Bengtsson M, Forootan A, Jonák J, et al. (2006) The real-time polymerase chain reaction. Mol Aspects of Med 27: 95-125.

34. Bar T, Kubista M, Tichopad A (2011)Validation of kinetics similarity in qPCR. Nucleic Acids Res 40: 1395-1406.

35. Hatt JK, Löffler FE (2012) Quantitative real-time PCR (qPCR) detection chemistries affect enumeration of the Dehalococcoides 16s rRNA gene in groundwater. J Microbiol Meth 88: 263-270.

36. Klein D (2002) Quantification using real-time PCR technology: applications and limitations. Trends Mol Med 8: 257-260

37. Munster VJ, Baas C, Lexmond P, Waldenström J, Wallensten A, et al. (2007) Spatial, temporal, and species variation in prevalence of influenza $A$ viruses in wild migratory birds. PLos Pathog 3: e61. 
Citation: Lu H, Tang Y, Lin L, Wolfgang DR (2016) Next-Generation Sequencing Confirmation of Real-Time RT-PCR False Positive Influenza-A Virus Detection in Waterfowl and Swine Swab Samples. Next Generat Sequenc \& Applic 3: 134. doi:10.4172/2469-9853.1000134

38. Jindal N, de Abin M, Primus AE, Raju S, Chander Y, et al. (2010) Comparison of cloacal and oropharyngeal samples for the detection of avian influenza virus in wild birds. Avian Dis 54: 115-119.

39. Hulsager CK, Breum S $\varnothing$, Trebbien AR, Handberg AK, Therkildsen OR, et al. (2012) Surveillance for avian influenza viruses in wild birds in Denmark and Greenland, 2007-10. Avian Dis 56: 992-998.

40. Lewis NS, Javakhishvili Z, Russell CA, Machablishvili A, Lexmond P, et al. (2013) Avian influenza virus surveillance in wild birds in Georgia: 2009-2011. Plos one 8: e58534.
41. Caporaso JG, Lauber CL, Walters WA, Berg-Lyons D, Huntley J, et al. (2012) Ultra-high-throughput microbial community analysis on the Illumina HiSeq and MiSeq platforms. Isme J 6: 1621-1624.

42. Lu H, Xie Z, Liu J, Lin L (2013) Studies on multiplex RT-PCR for detection of avian influenza virus type $A$ group and specific $\mathrm{H} 5$ and $\mathrm{H} 7$ subtypes. Avens Publishing Group, J Vet Sci Med.

43. Tang Y, Lu H, Sebastian A, Yeh YT, Praul CA, et al. (2015) Genomic characterization of a turkey reovirus field strain by Next-Generation Sequencing Infect Genet Evol 32: 313-321. 